\title{
Biosaintifika
}

Journal of Biology \& Biology Education

http://journal.unnes.ac.id/nju/index.php/biosaintifika

\section{Antimicrobial and Antioxidant Activities of Resins and Essential Oil From Pine (Pinus merkusi, Pinuso ocarpa, Pinus insularis) and Agathis (Agathis loranthifolia)}

\author{
${ }^{\square}$ Mardho Tillah $^{1}$, Irmanida Batubara ${ }^{1,2}$, Rita Kartika Sari ${ }^{3}$ \\ DOI: 10.15294/biosaintifika.v9i1.8371 \\ ${ }^{1}$ Department of Chemistry, Faculty of Mathematics and Natural Science, Bogor Agricultural University, \\ Indonesia \\ ${ }^{2}$ Tropical Biopharmaca Research Center, Bogor Agricultural University, Indonesia \\ ${ }^{3}$ Departement of Forest Products, Faculty of Forestry, Bogor Agricultural University, Indonesia
}

\section{History Article \\ Received 3 January 2017 Approved 27 February 2017 Published 1 April 2017}

\section{Keywords}

antibacterial activity; antioxidant; essential oil; resin

\begin{abstract}
The most common human pathogen that colonizes in a third of healthy people around the world are Staphylococcus aureus, and one of the materials allegedly able to overcome the pathogen is resin. Resin has been used in folk medicine for thousands of years to treat diseases. The antimicrobial activity of natural resins can be associated with a variety of organic compounds contained in them such as diterpenoids and triterpenoids. This research aimed to explore the antibacterial and antioxidant activities of Pinus merkusii, P. oocarpa, P. insularis, Agathis loranthifolia resins and essential oil. Resin was separated by distillation process to get essential oil and the residue was extracted using $n$-hexane, ethyl acetate (EtOAc), and methanol (MeOH). Antioxidant activity was performed by DPPH (1,1diphenyl-2-picryl hydrazyl) radical scavenging method. The antibacterial activity of resins and essential oil of the samples determined using the disc diffusion method against Staphylococcus aureus and Escherichia coli. The results showed that the yield of resin extract was ranging from $8.44 \%$ to $95.56 \%$. All extracts and essential oil could not inhibit $E$ coli growth but inhibit the $S$. aureus growth. This experiment concluded that resin $n$-hexane extract from P.oocarpa was the most potent as antibacterial activity against $S$. aureus. All of the samples used had less potential antioxidant activity compared to positive control ascorbic acid. Result of this study show that pine resin from Indonesia is potential as an antibacterial agent.
\end{abstract}

\section{How to Cite}

Tillah, M., Batubara, I. \& Sari, R. K. (2017). Antimicrobial and Antioxidant Activities of Resins and Essential Oil From Pine (Pinus merkusii, Pinuso ocarpa, Pinus insularis) and Agathis (Agathis loranthifolia). Biosaintifika: Journal of Biology \& Biology Education, 9(1), 134-139.

(C) 2017 Universitas Negeri Semarang
Correspondence Author:

Kampus IPB Dramaga Bogor, Jawa Barat 16680

E-mail: ime@apps.ipb.ac.id
p-ISSN 2085-191X e-ISSN 2338-7610 


\section{INTRODUCTION}

Plant resin has been used in folk medicine for thousands of years to treat disease, and used by the pharmaceutical industry predates the introduction of modern antibiotics. A variety of secondary metabolites contained in the resin plant the primary function is to protect plants against various predators and pathogenic microbes. The antimicrobial activity of the resins can be associated with various organic compounds such as alkaloids, phenols and terpenes (Dimkick et al., 2016). Toro et al. (2003) reported that the resin of Pinus elliottii showed anti-inflammatory activity and antiparasitic. Assimopoulou et al. (2005) reported natural resin from the Pistacia lentiscus shown has a good antioxidant activity.

Indonesia is the main producer of essential oil in the world. Turpentine oil is an essential oil which is obtained from pine resin distillation (Wijayanti et al., 2014). The terpenic oil was used by the eminent doctors of antiquity. Turpentine properties that helped acting against lung diseases and biliary lithiasis. Turpentine was recommended against blennorrhoea and cystitis in France. Turpentine was prescribed against neuralgias. The treatment of rheumatism, sciatica, nephritis, drop, constipation and mercury salivation also required turpentine.

The interest to antioxidant has increased because of its ability and high capacity in scavenging free radicals and protect the human body from oxidative damage. When the free radicals constantly and excessively produced in living systems, they can cause extensive damage to tissues and biomolecules that leads to a variety of pathological disorders such as aging, cancer, inflammation, Alzheimer's and cardiovascular disease. Butylated hydroxytoluene (BHT) and Butylated hydroxyanisole (BHA) is a synthetic antioxidant which the most commonly used, they has been reported to cause liver damage and carcinogenesis (Politeo et al., 2007). For this reason, finding a natural antioxidant derived from plants that may help attenuate oxidative damage and also cope with the adverse effects of synthetic antioxidants is necessary. Mohamed et al. (2014) found that resin of Commiphora myrrha has a good potential of the antioxidant with $\mathrm{IC}_{50}$ values for methanol and ethyl acetate extract 0.32 and $0.93 \mathrm{mg} / \mathrm{mL}$ respectively. Frateenale et al. (2011) reported that the $n$-hexane extract resin of $C$. erythraea have antioxidant activity which is quite good with $\mathrm{EC}_{50}$ value of $4.126 \mathrm{mg} / \mathrm{mL}$.

The most common human pathogen that colonizes in a third of healthy people around the world is Staphylococcus aureus. S. aureus also the etiological agent for a large number of human infections, including pneumonia, meningitis, toxic shock syndrome, bacteremia, and endocarditis. $S$. aureus is notorious for developing rapid resistance to antibiotics (Mun et al., 2013). Studies show that the natural resins of the genus Pinus and Agathis possess antibacterial activity. Resin of $P$. ponterosa effective against Gram-positive bacteria Bacillus subtilis (ATCC 9372) and Brevibacterium ammoniagenes (ATCC 6872) with a paper disc method (Himejima et al., 1992). Shuaib et al. (2013) reported that the resin of P. roxburghii showed better activity against Gram-positive than Gram-negative bacterial strains. Research conducted by Sipponen and Laitinen (2011) revealed that the pure resin of Picea abies significantly reduce the amount of bacteria inoculation $(S . a u$ reus, Escherichia coli, Pseudomonas aeruginosa, Bacillus subtilis, and Candida albicans) within 24 hours. In Malaysia, Agathis borneensis is traditionally used to treat fever. This species, and A. celebica of the Philippines, has shown activity against Plasmodium parasite responsible for malaria infection (Williams, 2011).

The aim of this research was to investigate the antimicrobial and antioxidant properties of some resin and essential oils against $S$. aureus and $E$. coli. Antibacterial activity determined using the disc diffusion method and to a test of antioxidant activity using the free radical scavenging activity of 1,1-diphenyl-2-picrylhydrazyl (DPPH) using both spectrophotometric assay and thinlayer chromatography (TLC) methods.

\section{METHODS}

\section{Plant materials and extraction methods}

Resins of pine and agathis were collected from Sukabumi, West Java, Indonesia. The sample was distilled to separate the volatile oil and re$\sin$. About $200 \mathrm{~g}$ resin was extracted by increasing the polarity of solvents $(400 \mathrm{~mL})$. First, $n$-hexane was used as solvent, then extraction was continued to the residue using ethyl acetate (EtOAc), and finally using methanol $(\mathrm{MeOH})$. The yield of all extract and volatile oils are determined after the extract were dried.

\section{Assays method}

Antimicrobial activities of the resins and essential oils from pine and agathis Staphylococcus aureus and Escherichia coliwere determined using the agar-disc diffusion method. Thebacteria were first incubated at $37^{\circ} \mathrm{C}$ for $24 \mathrm{~h}$ in nutrient broth. The agar medium was spread with the inoculum. 
Discs of sterile Whatman paper of $6 \mathrm{~mm}$ in diameter are deposited on the plates. Samples in various concentrations were injected into disc of sterile Whatman paper. After incubation at $37^{\circ} \mathrm{C}$ for $24 \mathrm{~h}$, the diameters of inhibition zones were measured in $\mathrm{mm}$ for the test organisms. Tetracycline was used as a positive control and the negative control was dimethyl sulfoxide (DMSO).

Assay of DPPH scavenging activity by spectrophotometry was conducted according to Batubara et al. (2009). First, the extracts were dissolved in ethanol, and different concentrations of each extract were used. In a total volume of 200 $\mu \mathrm{L}$, the assay mixture contained $100 \mu 1$ of the extract and $100 \mu 1$ of DPPH solution (4 mg DPPH in $100 \mathrm{ml}$ ethanol) were added to each well of a 96-well plate. After $30 \mathrm{~min}$, the absorbance of the mixture was measured at $514 \mathrm{~nm}$. The positive control was $(+)$ ascorbic acid while ethanol was used as the blank. The inhibition of DPPH radical was calculated as follows:

Inhibition $(\%)=\left[1-\left(\mathrm{A}_{\text {sample }}-\mathrm{A}_{\text {control }}\right) /\left(\mathrm{A}_{\text {blank }}-\right.\right.$ $\left.\left.\mathrm{A}_{\text {control }}\right)\right] \times 100 \%$

where, $\mathrm{A}_{\text {sample }}$ is the absorbance of the sample, $\mathrm{A}_{\text {control }}$ is the absorbance of (+)ascorbic acid as control and $\mathrm{A}_{\text {blank }}$ is the absorbance of ethanol as the blank. Each sample concentration of the samples and positive control were tested in triplicate.

Antioxidant bioautography was conducted according to Salazar-Aranda et al. (2011). Briefly, $10 \mu 1$ of each extract ( $2 \mathrm{~g}$ in ethanol) was applied to a TLC Silica gel $60 \mathrm{~F}_{254}$. Chromatography was conducted using $n$-hexane : ethyl acetate (73 : 27) as eluent. After elution process the plate was sprayed using a DPPH solution $(87 \mathrm{mg}$ in ethanol), 30 min later, the yellow spots from reduced DPPH were clearly observed against a purple background.

\section{RESULTS AND DISCUSSION}

Extraction of pine and agathis resin has been done by increasing polarity solvent. The extraction method used was maceration. The extraction method used was easy and done at room temperature, so it did not destroy the chemical compounds in the sample.Extraction of pine and agathis resin yielded shown in Table 1 . For pine all samples have been extracted in the $n$-hexane, there is no residues found and the extraction process not continue to more polar solvent. For agathis $8.437 \%$ can be extracted in $n$-hexane, and the residues extracted by EtOAc and continue with $\mathrm{MeOH}$. The result shows that the major compound in pine is a non polar compound which can be extracted in $n$-hexane while for agathis is semi-polar extract which can be extracted in EtOAc.

Table 1. Yield extract of pine and agathis

\begin{tabular}{lccc}
\hline \multirow{2}{*}{ Samples } & \multicolumn{3}{c}{ Yield (\%) } \\
\cline { 2 - 4 } & n-hexane & EtOAc & $\mathrm{MeOH}$ \\
\hline P. merkusii & 93.581 & - & - \\
P. oocarpa & 76.434 & - & - \\
P. insularis & 95.557 & - & - \\
$\begin{array}{l}\text { Agathis } \\
\text { loranthifolia }\end{array}$ & 8.437 & 11.482 & 10.533 \\
\hline
\end{tabular}

Some bacteria are pathogenic, play an active role as a cause of disease. Based on the type of pathogenic bacteria, it can be divided into Grampositive and Gram-negative bacteria. Staphylococcus aureus is Gram-positive bacteria that cause skin diseases such as boils, burns and infections; whereas Escherichia coli causes acute diarrheal disease in Gram-negative bacteria. The antimicrobial activity of resin extract from $n$-hexane $P$. merkusii, $n$ hexane $P$. insularis, $n$-hexane $P$. oocarpa, $n$-hexane A. loranthifolia, EtOAc A. loranthifolia, $\mathrm{MeOH} A$. loranthifolia, and essential oils from turpentine $P$. merkusii, turpentine $P$. insularis, turpentine $P$. oocarpa against $S$. aureus Gram-positive bacteria and $E$. coli Gram-negative bacteria as zone inhibition is shown in Table 2. In this research, the antimicrobial activities of the resin extract and essential oil in four different concentrations of 125 to $1000 \mu \mathrm{g} / \mathrm{mL}$, were compared with those of tetracycline used as positive controls.

The antimicrobial showed that resin extract from $P$. oocarpa has the diameter inhibition from concentration of $500 \mu \mathrm{g} / \mathrm{mL}$, while the $P$. insularis and $P$. merkusii has diameter inhibition from $1000 \mu \mathrm{g} / \mathrm{mL}$. This phenomenon show is that the resin extract of $P$. oocarpa was the most active as antibacterial against Staphylococcus aureus than all samples. Meanwhile the Escherichia coli bacteria samples showed no activity. This goes along with research conducted by Savluchinske-Feio et al (2006) who reported that resin of Pinusponterosa effective against Gram-positive bacteria Bacillus subtilis (ATCC 9372) and Brevibacteriumammoniagenes (ATCC 6872) with a paper disc method. Instead, the resin of Pinusnigra ineffective in testing fungi and Gram-negative bacteria.

Resin is a mixture of resin acids mainly composed of abietic acid, palustric, neoabietic acid, and the dehydroabietic acid, as well as some non-abietane diterpenoid, such as acid and isopimarik pimarik (Gonzalez, 2014). Studies on 
Mardho Tillah et al. / Biosaintifika 9 (1) (2017) 134-139

Table 2. Antimicrobial activity of extracts against bacterial strains tested using on agar-disc diffusion method.

\begin{tabular}{|c|c|c|c|c|c|c|c|c|}
\hline \multirow{2}{*}{ Resin / essential oils } & \multicolumn{4}{|c|}{ Staphylococcus aureus } & \multicolumn{4}{|c|}{ Escherichia coli } \\
\hline & 1000 & 500 & 250 & 125 & 1000 & 500 & 250 & 125 \\
\hline$n$-hexane $P$. Merkusii & 7.71 & - & - & - & - & - & - & - \\
\hline$n$-hexane $P$. oocarpa & 11.20 & 8.20 & - & - & - & - & - & - \\
\hline$n$-hexane $P$. insularis & 8.20 & - & - & - & - & - & - & - \\
\hline$n$ - hexane $A$. loranthifolia & - & - & - & - & - & - & - & - \\
\hline EtOAc $A$. Loranthifolia & - & - & - & - & - & - & - & - \\
\hline $\mathrm{MeOH}$ A. Loranthifolia & - & - & - & - & - & - & - & - \\
\hline Turpentine $P$. merkusii & - & - & - & - & - & - & - & - \\
\hline Turpentine $P$. oocarpa & - & - & - & - & - & - & - & - \\
\hline Turpentine $P$. insularis & - & - & - & - & - & - & - & - \\
\hline Tetracycline & $\mathrm{nt}$ & $\mathrm{Nt}$ & 23.2 & $\mathrm{nt}$ & $\mathrm{nt}$ & $\mathrm{nt}$ & 27.1 & $\mathrm{Nt}$ \\
\hline
\end{tabular}

nt : not tested

resin and the resin acids demonstrated their antibacterial effects, mainly against Gram-positive bacteria. The abietic acids were stronger antibacterial agents than pimaric and labdane acids, and among the individual resin acids, dehydroabietic acid was generally the most potent (Shuaib, et al., 2013). Diterpene antimicrobial activity against certain microorganisms associated with the presence of the group in the molecule functional groups such as carboxyl, hydroxyl, aldehyde or ketone and among other groups. The ability of these functional groups act as donor or acceptor of hydrogen by microbial targets, and the importance of the position of the functional groups in the framework of the hydrocarbon causes the formation of several important structure-activity relationships (Savluchinske-Feio, et al., 2006). Antimicrobial diterpenoids can act on multiple biochemical targets of the microorganisms and it has been suggested that the activity of these compounds results from their ability to cross or damage microbial cell membranes due to their amphiphilic nature. The interaction of abietic acid with phospholipid membranes has been studied and its bacteriolytic action against $B$. cereus has been established (Urzua, et al., 2008).

Antioxidant activities of all the extracts were analyzed by a DPPH free radical assay using spectrophotometric. $\mathrm{IC}_{50}$ value indicated the concentration of sample that could inhibit 50 percent reduction of DPPH radical (Table 3). The lowest $\mathrm{IC}_{50}$ value means the most active sample as antioxidant. The extract was also analyzed by a DPPH free radical assay using TLC.

The result showed that resin extract from $n$-hexane $P$. merkusii has the lowest $\mathrm{IC}_{50}$ value, it mean that resin extract from $n$-hexane $P$. merkusii

was the most potent as antioxidant compare with the other sample. All the samples showed the less potential of antioxidant compared to control positive (ascorbic acid). Previous study found that the essential oil from fresh fruits of $P$. roxburghii showed only negligible radical scavenging activity. Salem et al (2014) reported that total antioxidant activities (TAA\%) of the essential oils of $P$. roxburghii Sarg. from wood $(82 \pm 2.12 \%)$ and bark $(85 \pm 1.24 \%)$ were higher than tannic acid and essential oils of needles $(50 \pm 2.24 \%)$ was lower that of tannic acid.

Table 3. Antioxidant activities of resins extract and essential oils

\begin{tabular}{ll}
\hline Samples & $\mathrm{IC}_{50}(\mathrm{mg} / \mathrm{mL})$ \\
\hline$n$ - hexane $P$. oocarpa & 154.500 \\
$n$ - hexane $P$. insularis & 99.328 \\
$n$ - hexane $P$. merkusii & 60.203 \\
$n$ - hexane A. loranthifolia & 438.551 \\
MeOHA. loranthifolia & 313.510 \\
EtOAc $A$. loranthifolia & 245.990 \\
TurpentineP. insularis & 359.687 \\
Turpentine $P$. oocarpa & 1194.250 \\
Turpentine $P$. merkusii & 1119.960 \\
Ascorbic acid & 0.0052 \\
\hline
\end{tabular}

Qualitative test of the extract of pine resin, agathis and essential oil was conducted to determine content of the extract compounds that have antioxidant activity. Qualitative test was done by thin layer chromatography and DPPH reagent to detect compounds that have the ability to reduce DPPH by sample and gives a yellow color on 


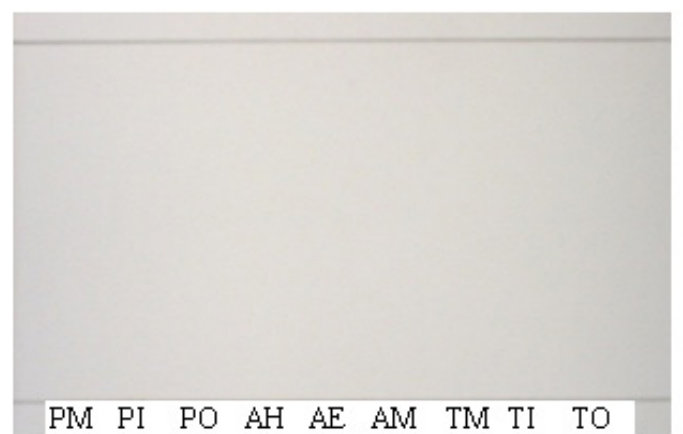

a

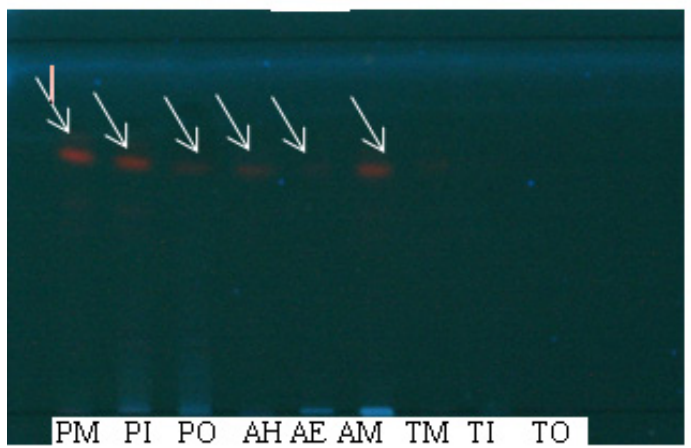

$\mathrm{C}$

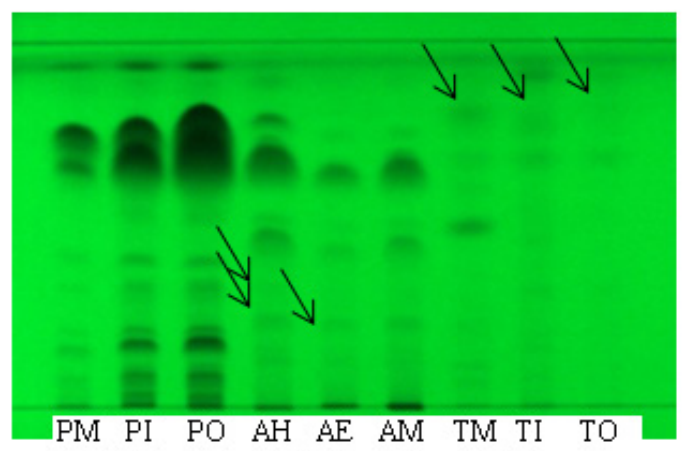

b

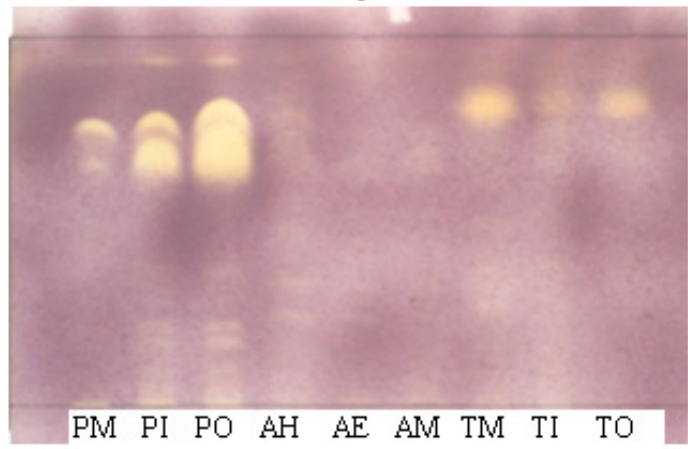

d

Figure 1. Chromatogram bioautography antioxidants; using a detection reagent

the spot are active as an antioxidant. From the bioautography assay as shown in Figure 1 resin extract $n$-hexane from $P$. oocarpa, $P$. insularis and $P$. merkusii displayed a strong antioxidant activity compared to resin extract $n$-hexane $A$. loranthifolia, $\mathrm{MeOH}$ A. loranthifolia, EtOAc A. loranthifolia and all essential oil.

Rf value of resin extract from $n$-hexane $P$. merkusii, $n$-hexane $P$. insularis, $n$-hexane $P$. oocarpa, $n$-hexane A. loranthifolia, EtOAc A. loranthifolia, $\mathrm{MeOH} A$. loranthifolia, and essential oils from turpentine $P$. merkusii, turpentine $P$. insularis turpentine $P$. oocarpa ranged between $0.15-0.93$ before sprayed by DPPH in $254 \mathrm{~nm}$. In chromatogram that seen under UV light at $366 \mathrm{~nm}$ (Figure 1.c) resin extract from $P$. merkusii (0.74), $n$-hexane $P$. insularis (Rf 0.67), $n$-hexane $P$. oocarpa (Rf 0.65), n-hexane A. loranthifolia (Rf 0.64), EtOAc A. loranthifolia ( $\mathrm{Rf} 0.64$ ), $\mathrm{MeOH} A$. loranthifolia ( $\mathrm{Rf}$ 0.65 ) showed a red spot. It is suspected that resins extracts contain terpenoids compound.

After sprayed by DPPH (Figure 1.d) there were 3 spots (Rf $0.65,0.80$ and 0.93 ) for $n$ - hexane $P$. merkusii, 5 spots (Rf $0.18,0.20,0.67,0.80$ and 0.92 ) for $n$-hexane $P$. insularis and 5 spots (Rf 0.18, 0.21, 0.71, 0.80 and 0.92) for $n$-hexane $P$. oocarpa active as an antioxidant. It was characterized by the appearance of yellow color on the chromatogram bioautography. While on $n$ - hexane $A$. loranthifolia, EtOAc A. loranthifolia, $\mathrm{MeOH}$
A. loranthifolia yellow spots were disguised, indicating samples inactive as an antioxidant. For essential oils turpentine $P$. merkusii, turpentine $P$. insularis, turpentine $P$. oocarpa with $\mathrm{Rf}$ value 0.79 , 0.82 and 0.82 respectively, there was a faint yellow spots that signaled it's less antioxidant activity.

DPPH (a)visible light (b) $254 \mathrm{~nm}$ (c) 366 $\mathrm{nm}$ before sprayed by DPPH; (d) visible light after sprayed by DPPH;PM: $n$ - hexane $P$. merkusii; PI: $n$-hexane P. insularis; $\mathrm{PO}$ - hexane P. oocarpa; AH: $n$ - hexane A. loranthifolia; AE: EtOAc A. loranthifolia; $\mathrm{AM}: \mathrm{MeOH}$ A. loranthifolia; TM: Terpentin P. merkusii; TI: Terpentin P. insularis; TO: Terpentin P. oocarpa

\section{CONCLUSION}

In this study, the antimicrobial and antioxidant activities of resin extract essential oil from from $n$-hexane $P$. merkusii, $n$-hexane $P$. insularis, $n$ hexane $P$. oocarpa, $n$-hexane $A$. loranthifolia, EtOAc A. loranthifolia, $\mathrm{MeOH}$ A. loranthifolia, turpentine $P$. merkusii, turpentine $P$. insularisand turpentine $P$. oocarpa were investigated. The results indicated that resin extract from $n$-hexane $P$. oocarpa was the most potential as antibacterial compared with other sample. For antioxidant extract $n$-hexane $P$. merkusii had the lowest $\mathrm{IC}_{50}$ value compared to other extract. Red spots on the chromatogram 
seen under UV light at $366 \mathrm{~nm}$ suspected is a terpenoids group.

\section{REFERENCES}

Assimopoulou, A. N., Zlatanos, S. N., \& Papageorgiou, V. P. (2005). Antioxidant activity of natural resins and bioactive triterpenes in oil substrates. Food chemistry, 92(4), 721-727.

Batubara, I., Mitsunaga, T., \& Ohasi, H. (2009). Screening antiacne potency of Indonesian medicinal plants; antibacterial, lipase inhibition, and antioxidant activities. J Wood Sci, 55(3), 230-235

Dimkic, I., Ristivojevic, P., Janakiev, T., Beric, T., Trifkovic, J., Milojkovic-Opsenica, J., \& Stankovic, S. (2016). Phenolic profiles and antimicrobial activity of various plant resins as potential botanical sources of Serbian propolis. Industrial Crops and Products, 94, 856-871.

Gonzalez, M. A. (2014). Synthetic derivatives of aromatic abietane diterpenoids and their biological activities. European Journal of Medicinal Chemistry, 87, 834-842.

Himejima, M., Hobson, K. R., Otsuka, T., Wood, D. L., \& Kubo, I. (1992). Antimicrobial terpenes from oleoresin of ponderosa pine tree Pinus Ponderosa: a defense mechanism against microbial invasion. Journal of Chemical Ecology. 18(10), 1809-1818.

Mohamed, A. A., Ali, S. I., EL-Baz, F. K., Hegazy, A. K., \& Kord, M. A. (2014). Chemical composition of essential oil and in vitro antioxidant and antimicrobial activities of crude extracts of Commiphoramyrrha resin. Industrial Crops and Products, 57, 10-16.

Mun Su-Hyun, Joung Dae-Ki, Kim Yong-Sik, Kang Ok-Hwa, Kim Sung-Bae, Seo Yun-Soo, Kim Youn-Chul, Lee Dong-Sung, Shin Dong-Won, Kweon Kee-Tae, \& Kwon Dong-Yeul. (2013). Synergistic antibacterial effect of curcumin against methicillin-resistant Staphylococcus aureus. Phytomedicine, 20(8), 714-718.

Politeo, O., Jukic, M., \& Milos, M. (2007). Chemical composition and antioxidant capacity of free volatile aglycones from basil (Ocimumbasilicum L.) compared with its essential oil. Food Chem, 101(1), 379-385.

Salazar-Aranda, R., Pérez-Lopez, L. A., Lopez-Arroyo, J., Alanís-Garza, B. A., \& Waksman de Torres, N. (2011). Antimicrobial and antioxidant activities of plants from northeast of Mexico. Evidence-Based Complementary and Alternative Medicine, 2011.

Salem, M. Z. M., Ali, H. M. , \& Basalah, M. O. (2014). Essential Oils from Wood, Bark, and Needles of PinusroxburghiiSarg from Alexandria, Egypt: Antibacterial and Antioxidant Activities. BioResources, 9(4), 7454-7466.

Savluchinske-Feio, S., Curto, M. J. M., Gigante, B., \& Roseiro, J. C. (2006). Antimicrobial activity of resin acid derivatives. Appl Microbiol Biotechnol, 72(3), 430-436.

Shuaib, M., Ali, A., Ali, M., Panda, B., \& Ahmad, M. (2013). Antibacterial activity of resin rich plant extracts. Journal of Pharmacy and Bioallied Sciences, 5(4), 265-269.

Sipponen, A., \& Laitinen, K. (2011). Antimicrobial properties of natural coniferous rosin in the European Pharmacopoeia challenge test. APMIS, 119(10), 720-724.

Tóro, R. M., Gessner, A. A. F., Furtado, N. A. J. C., Ceccarelli, P. S., Sérgio de Albuquerque, \& Bastos, J. K. (2003). Activity of the Pinuselliottii resin compounds against Lernaeacyprinacea in vitro. Veterinary Parasitology, 118(1), 143-149.

Urzúa, A., Rezende, M. C., Mascayano, C., \& Vásquez, L. (2008). A Structure-Activity study of antibacterial diterpenoids. Molecules, 13(4), 882-891.

Wijayati, N., Astutiningsih, C., \& Mulyati, S. (2014). Transformasi $\alpha$-Pinena dengan Bakteri Pseudomonas aeruginosa ATCC 25923. Biosaintifika: Journal of Biology \& Biology Education, 6(1), 2428.

Williams, C. J. (2011). Medical Plants in Australia Volume 2 Gums, Resins, Tannin and essential Oils. Australia: Rosenberg. 